\title{
T-Cell Prolymphocytic Leukemia, Cerebriform Cell Variant
}

National Cancer Institute

\section{Source}

National Cancer Institute. T-Cell Prolymphocytic Leukemia, Cerebriform Cell Variant. NCI

Thesaurus. Code C36271.

A T-cell prolymphocytic leukemia characterized by the presence of neoplastic prolymphocytes with irregular or cerebriform nuclear outline. 